\title{
Occurence of the Thermophilic Mediterranean Parrot Fish Sparisoma cretense (Linneaus, 1758) (Teleostei: Scaridae) in Dikili Bay, Northern Aegean Sea, Turkey
}

\author{
Sezginer TUNCER ${ }^{1} \quad$ Hatice TORCU KOC ${ }^{2 *} \quad$ RIdvan Erdem KANAT $^{3}$ \\ ${ }^{I}$ University of Çanakkale Onsekiz Mart, Faculty of Marine Science and Technology, Department of Marine Science and Limnology, Çanakkale, Turkey \\ ${ }^{2}$ University of Balikesir, Faculty of Science and Arts, Department of Biology, Ballkesir, Turkey \\ ${ }^{3}$ Graduate School of Natural and Applied Sciences, Department of Marine Science and Limnology,Çanakkale Onsekiz Mart University, Çanakkale, Turkey
}

How to cite: Tuncer, S., Torcu Koç, H. \& Kanat, R.E. (2020). Occurence of the Thermophilic Mediterranean Parrot Fish Sparisoma cretense (Linneaus, 1758) (Teleostei: Scaridae) in Dikili Bay, Northern Aegean Sea, Turkey. J. Anatolian Env. and Anim. Sciences, 5(4), 759-764.

Atıf yapmak için: : Tuncer, S., Torcu Koç, H. \& Kanat, R.E. (2020). Dikili Körfezi’nde (Kuzey Ege Denizi, Türkiye) Termofil Akdeniz Papağan Balığı Sparisoma cretense (Linneaus, 1758) (Teleostei: Scaridae)'nin Bulunuşu. Anadolu Çev. ve Hay. Dergisi, 5(4), 759-764.

(iD): https://orcid.org/0000-0003-0678-1509

(iD): https://orcid.org/0000-0002-5892-7365

(iD) : https://orcid.org/0000-0002-1452-8856

*Corresponding author's:

Hatice TORCU KOC

University of Balikesir, Faculty of Science and

Arts, Department of Biology, Cagis Campus,

Balıkesir, Turkey.

凶: htorcukoc@hotmail.com

Mobile telephone : +90 (532) 4276058
Abstract: On November 2019, one mature male specimen of the Mediterranean parrotfish Sparisoma cretense (L.) was caught by a long line in Dikili Bay. This paper declares the northernmost distribution of $S$. cretense in the northern Aegean Sea. Here, the detailed morphometric and meristic characteristics of this species are given.

Keywords: Dikili Bay, Mediterranean parrotfish, morphometry, Sparisoma cretense.

\section{Dikili Körfezi’nde (Kuzey Ege Denizi, Türkiye) Termofil Akdeniz Papağan Balığı Sparisoma cretense (Linneaus, 1758) (Teleostei: Scaridae)'nin Bulunuşu}

*Sorumlu yazar:

Hatice TORCU KOC

Balıkesir Üniversitesi, Fen Edebiyat Fakültesi

Biyoloji Bölümü, Balıkesir, Türkiye.

凶: htorcukoc@hotmail.com

Cep telefonu : +90 (532) 4276058
Öz: Kasım 2019'da Akdeniz papağan balığı, Sparisoma ceretense (L.)'nin olgun bir erkek bireyi Dikili Körfezi'nde olta ile yakalandı. Bu makale S. cretense' nin kuzey Ege Denizi'ndeki kuzeye doğru dağılımını açıklamaktadır. Burada, türün detaylı morfometrik ve meristik özellikler verilmiştir.

Anahtar kelimeler: Dikili Körfezi, Akdeniz papağan balığı, morphometri, Sparisoma cretense.

\section{INTRODUCTION}

In the last two decades, the advance of thermophilic species represented the first and most cited evidence of the linkage between climate change and distribution patterns of Mediterranean Sea biodiversity (Francour et al., 1994; Riera et al., 1995). Global climate change is impacting and will continue to impact marine and estuarine fish and fisheries.
Climate warming leads species to drive their ranges north in the Northern Hemisphere (Parmesan et al., 1999; Walther et al., 2002). More than 30 Mediterranean warm-water indigenous fish species have now been pointed out the north of their original south geographical distribution and colder sectors of the basin has been reported (Dulčić \& Pallaro, 2001; Guidetti \& Boero, 2001, 2002; Bello et al., 2004; Azzurro et al., 2011; Kruschel et al., 2012; Perdikaris et al., 
2012). According to Azzurro (2008), the native thermophilic species appearing northern than the known range could serve as a good indicator to show the changes in seawater temperature and global heating.

Scaridae family consist of 10 genera and 88 species, two in the Mediterranean, the native Sparisoma cretense (Linnaeus, 1758) and the Lessepsian migrant Scarus ghobban Forsskål, 1775 (Golani et al., 2006; Froese \& Pauly, 2018). S. crentense is a thermophilic marine, seagrass meadows and reef asscociated fish which distributes from Southern and Eastern Atlantic to the Canary Islands, Mediterranean Sea, and Turkish Seas between shallow water and about 50 meters at depth (Randall, 1990; Guidetti \& Boero, 2002; Abecasis et al., 2008; Rodjan \& Lewis, 2006; Lök et al., 2008; Kruschel et al., 2012; Espino et al., 2015; Louisy, 2015; Ventura et al., 2019). This distribution pattern may lead ones to think of this fish as Mediterranean thermophilic southern fish (Guidetti \& Boero, 2001). The fish feeds on algae and small invertebrates (Quignard \& Pras, 1986), with specialized pharyngeal bones and muscles (Monod et al., 1994; Bullock \& Monod, 1997). The species commonly measures from 14 to $32 \mathrm{~cm}$ in total length (Petrakis \& Papaconstantinou, 1990; Kruschel et al., 2012), but might grow as big as $52 \mathrm{~cm}$ (total length) (Pallaoro \& Dulcic, 2004; Afonso et al., 2008; Oliveira et al., 2015; Filiz \& Sevingel, 2015). Reproduction occurs from July to September (Petrakis \& Papaconstantinou, 1990) with juveniles recruiting in late summer (Guidetti \& Boero, 2002). Parrotfish is observed rarely along the Mediterranean Sea and Turkish coasts (Bianchi \& Morri, 1994; Başusta \& Erdem, 2000; Dulčić \& Pallaoro, 2001; Torcu et al. 2001; Guidetti \& Boero, 2002; Öğretmen et al., 2005; Fricke et al., 2007; Akyol et al., 2011; Azzuro et al., 2013; Bilecenoğlu et al., 2014; Çoker \& Akyol, 2014; Filiz \& Sevingel, 2015;
Yapıc1 et al., 2016) and and also recorded from Köycegiz Lagoon/Dalyan River system and Kuşadası Gulf by Akın et al. (2005) and Lök et al. (2008), respectively.

The aim in this study, is to present as a new additional record, confirming this thermophilic Mediterranean parrotfish population to distribute northwards in northern coasts of Aegean Sea.

\section{MATERIAL AND METHOD}

One mature male specimen $(28.50 \mathrm{~cm}$ TL) was caught by a long line by Ridvan Erdem Kanat from coast of Dikili Bay, northern Aegean Sea (39 $4^{\prime} 56^{\prime \prime} \mathrm{N}$, long $26^{\circ} 48^{\prime}$ $25^{\prime \prime} \mathrm{E}$ ) (Figure 1). The sample was identified at species level according to FishBase (Quignard \& Pras, 1986b; Randall, 1990).

All measurements including counts and weight were carried out on fresh fish, using a digital caliper of 0.05 $\mathrm{mm}$ accuracy and digital balance of $0.01 \mathrm{~g}$. The material was photographed, dissected and then stored in the collections of the Piri Reis Museum, University of Çanakkale. The standard and total lengths (TL and SL) were taken with a dial caliper of $0.05 \mathrm{~mm}$ accuracy and weight $( \pm 0.01$ g.) was measured; the material was photographed and then, was fixed in $10 \%$ buffered formaldehyde, and subsequently preserved in $75 \%$ ethanol and deposited in the collections of the Piri Reis Museum, University of Çanakkale.

\section{RESULTS AND DISCUSSION}

Total length and weight of this specimen were measured as $28.50 \mathrm{~cm}$ and $400 \mathrm{~g}$. respectively. Some morphometric and meristic features of Mediterranean parrotfish are given in Table 1.

Table 1. Morphometric (mm, cm) and meristic features of Spariosoma cretense specimen captured from the coast of Dikili Bay on November 2019.

\begin{tabular}{|c|c|c|c|c|c|c|}
\hline References & Abeces et al.(2008) & & pici et al. & & Kampouris \& Batjakas (2018) & Present Study* \\
\hline $\mathbf{N}$ & 1 & 1 & 2 & 3 & 1 & 1 \\
\hline Total length (TL) & 79.23 & 222.0 & 223.0 & 225.0 & 267.57 & 28.50 \\
\hline Standard length (SL) & 65.75 & 201.0 & 210.0 & 226.0 & 218.78 . & 24.20 \\
\hline Snout length & 5.94 & - & - & - & 24.27 & 3.7 \\
\hline Head length (HL) & 19.41 & 55.33 & 58.04 & 69.60 & 65.36 & 7.5 \\
\hline Body depth (BD) & 19.92 & 60.15 & 61.65 & 73.89 & 71.14 & 8.0 \\
\hline Predorsal length (PDL) & - & 55.26 & 58.63 & 71.43 & - & - \\
\hline Preanal length (PAL) & - & 113.49 & 115.24 & 136.48 & - & - \\
\hline Caudal peduncle depth (CPD) & - & - & - & - & 34.24 & 2.5 \\
\hline Preorbital length (POL) & - & 18.49 & 22.58 & 29.52 & - & 1.7 \\
\hline Interorbital length (IOL) & - & 16.44 & 16.68 & 16.68 & - & - \\
\hline Eye diameter(ED) & 5.51 & 10.96 & 11.02 & 13.04 & 11.76 & 1.3 \\
\hline D & VIII+10 & VIII+10 & VIII+10 & $\mathrm{XI}+10$ & $\mathrm{XI}+10$ & $\mathrm{XII}+10$ \\
\hline A & III +9 & $\mathrm{III}+9$ & III +9 & III+9 & III +9 & $\mathrm{III}+10$ \\
\hline V & - & $\mathrm{I}+5$ & $\mathrm{I}+5$ & $\mathrm{I}+5$ & $\mathrm{I}+5$ & $\mathrm{I}+5$ \\
\hline $\mathbf{P}$ & - & 12 & 12 & 12 & 12 & 12 \\
\hline Lateral line & - & 22 & 21 & 21 & - & 21 \\
\hline Weight (g.) & - & - & - & - & 317 & 400 \\
\hline
\end{tabular}

Characteristic morphological properties are presented with a sexual dichromatism which is presented with the male showing a grey-brown coloration while the female is generally reddish with a large grey spot on the rear part of the head and a yellow spot on the upper part of the caudal peduncle (Tortonese, 1971 in De Girolamo et al., 1999). It has a fused, beak-like jaw scraping algae and sea grass from the substrate (Guidetti \& Boero, 2002). Due to its 
grazing, the parrotfish seems to be a more competitive to Treptachanta ballesterosii than the other native herbivorous species Sarpa salpa in Mediterranean Sea (Marletta \& Lombardo, 2020).

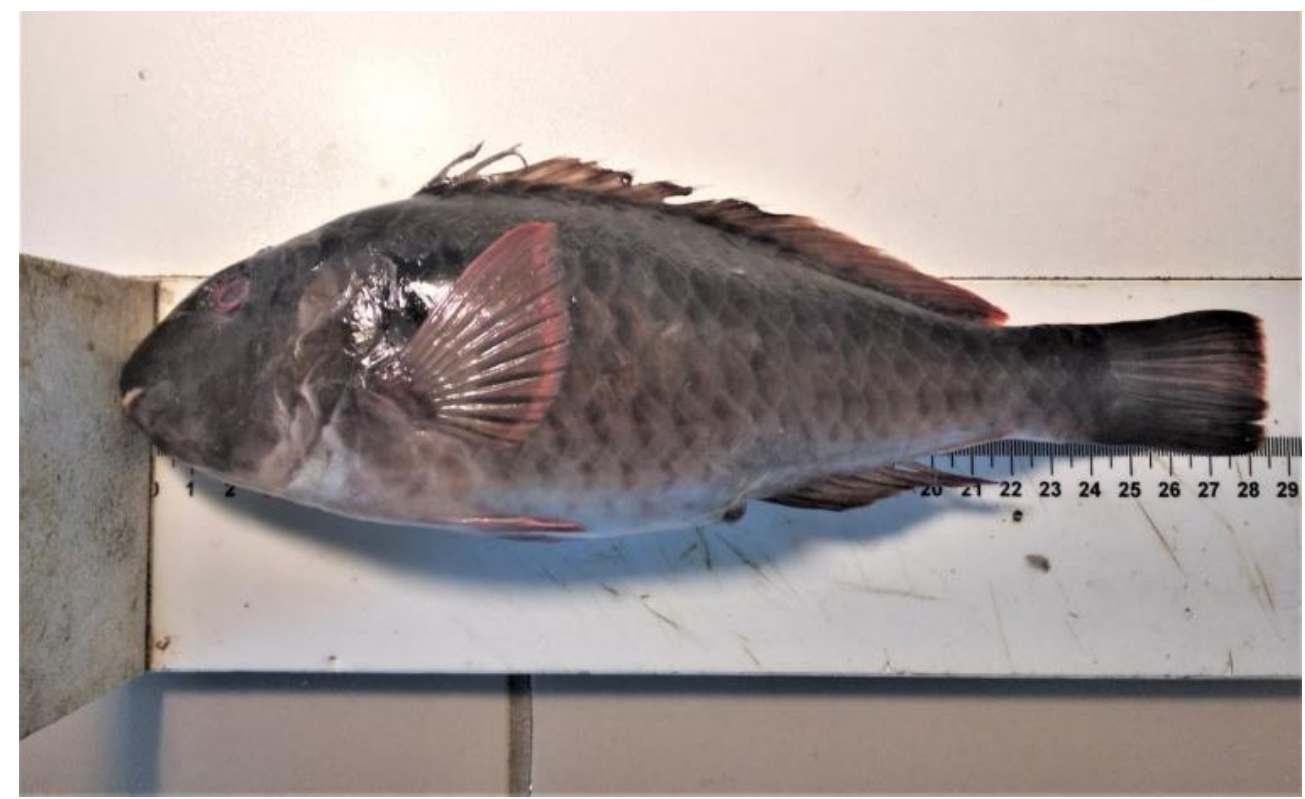

Figure 1. A male Spariosoma cretense specimen $(28.50 \mathrm{~cm}$ TL) captured in Dikili Bay, the northern Aegean Sea (Original photo by Kanat).

One mature specimen was $28.50 \mathrm{~cm}$ in total length According to De Girolamo et al. (1999), we included the specimen into adults (estimated total length (TL) $\geq 12 \mathrm{~cm}$ ). The morphometric measurements and meristic counts which were given in Table 1 were similar with the previous literature by Kampouris \& Batjakas (2018), except for those given by Abeces et al., (2008) and Yapicı et al., (2016).

Guidetti \& Boero (2002) mentioned that the species which is relatively rare there, could establish and constitute populations succesfully other than its typical distribution. Global heating of seas is an important factor that leads the reconstruction of the Mediterranean marine biodiversity (Bianchi \& Morri, 2004; Lejeusne et al., 2010).

Global change is having an ever increasing influence on the abundance and distribution of living organisms worldwide (Parmesan, 2003). As for the Mediterranean Sea, recently, the increasing of sea water temperature causes the shift and nortward migration of many invertebrate and vertebrate taxa that are now living their natural biogeographical ranges. Therefore, some species, typically known as thermophilic are succesfully colonizing in the north. The marine biodiversity of the Mediterranean is undergoing changes which can be characterized as a process towards tropicalization and the increasing of warm-water biota (Bianchi \& Morri, 2003). A number of native species with tropical or subtropical affinity seem to have already moved towards the northern and colder sectors of the Mediterranean (Azzurro, 2008; Ben Rais Lasram \& Mouillot, 2009). As the water temperature increases, the species such as $S$. cretense which exists naturally in the southern Mediterranean Sea spreads northward from the native warm water ecosystem. This phenemenon has been termed as "meridionalisation" (Azzurro, 2008, 2011; Boero et al., 2008, Marletta \& Lombardo, 2020).

In the light of this view, it can be thought that the native thermophilic species appearing northern than the typically geographic distribution range could serve as a clear indicator by providing the first sign of changes in seawater temperature (Azzurro, 2008).

The northernward spreading of this Mediterranean parrotfish is not a single event and an ongoing process. Thus, monitoring of distribution of thermophilic indicator species, such as the parrotfish may also start to occur supporting the hypothesis that fish migrations may be related with climatic change, namely water warming and give some information to show possible changes on the Mediterranean marine ecosystems and to form stable populations outside its own region.

As a conclusion, the occurence of $S$. cretense at Dikili Bay confirms an additional knowledge on its presence in the northern Aegean Sea of Turkey. As recognizing its growth, spawning and recruitment (Albouy et al., 2014; Marras et al., 2015) in benthic biodiversity (Lewis \& Wainwright, 1985) and there is a little knowledge about the species biology and ecology, thus, further studies are required to track the population dynamics of this northward expanding species through the northern sectors of the Mediterranean basin. Although S. cretense which is not a commercial species in general (Fisher et al., 1987) and included as Least Concern in The IUCN Red List of Threatened Species (Pollard et al., 2012), this species is 
highly valuable for both local recreational and commercial fisheries in Canary Islands (Bortone et al., 1991). It is also important for diversity of Dikili Bay ichthyofauna.

Conflict of Interest: The authors declare that they have no conflict of interest.

Ethical approval: All applicable international, national, and/or institutional guidelines for the care and use of animals were followed.

\section{REFERENCES}

Abecasis, D., Bentes, L., Ribeiro, J., Machado, D., Oliveira, F., Veiga, P., J.M.S., Gonçalves, J.M.S. \& Erzini, K. (2008). First record of the Mediterranean parrotfish, Sparisoma cretense in Ria Formosa (south Portugal). Marine Biodiversity Records, 1, E27. DOI: 10.1017/S175526720600248X

Afonso, P., Morato, T. \& Santos, R.S. (2008). Spatial patterns in reproductive traits of the temperate parrotfish Sparisoma cretense. Fisheries Research, 90, 92-99.

Akın, S., Buhan, E., Winemiller, K.O., \& Yılmaz, H. (2005). Fish assemblage structure of Köycegiz Lagoon-estuary, Turkey: spatial and temporal distribution patterns in relation to environmental variation. Estuarine Coastal and Shelf Sciences, 64, 671-684.

Akyol, O., Çoker, T. \& Perçin, F. (2011). The very rare and little-known fishes along the coasts of Izmir (Aegean Sea, Turkey) in the past 40 years (19692008). Journal of Applied Ichthyology, 27, 13371345.

Albouy, C., Velez, L., Coll, M., Colloca, F., Le Loc'h, F, Mouillot, D. \& Gravel, D. (2014). From projected species distribution to foodweb structure under climate change. Global Change Biology, 20, 730-741. DOI: 10.1111/gcb.12467

Azzurro, E. (2008). The advance of thermophilic fishes in the Mediterranean Sea: overview and methodological questions, In: Briand, F. (Ed), Climate warming and related changes in Mediterranean marine biota. CIESM Workshop Monographs, 35, 39-46, Monaco.

Azzurro, E., Moschella, P. \& Maynou, F., (2011). Tracking signals of change in Mediterranean fish diversity based on local ecological knowledge. PloS one, 6(9), e24885. DOI: 10.1371/journal.pone.0024885

Başusta, N. \& Erdem, Ü. (2000). İskenderun Körfezi Balıkları Üzerine Bir Araştırma (A study on the pelagic and demersal fishes of Iskenderun Bay). Turkish Journal of Zoology, 24 (Suppl.), 1-19.

Bello, G., Casavola, N. \& Rizzi, E. (2004). Aliens and visitors in the southern Adriatic Sea: effects of tropicalization. Rapports de la Commission
Internationale pour l'Exploration Scientifique de la Mer Méditerranée, 37, 491.

Ben Rais Lasram, F. \& Mouillot, D. (2009). Increasing southern invasion enhances congruence between endemic and exotic Mediterranean fish fauna. Biologic Invasions, 11(3), 697-711.

Bianchi, C.N. \& Morri, C. (1994). Southern species in the Ligurian Sea (northern Mediterranean): new records and a review. Bollettino dei Musei e Degli Istituti Biologici dell'Università di Genova, 58(59), 181-197.

Bianchi, C.N. \& Morri, C. (2003). Global sea warming and "tropicalization" of the Mediterranean Sea: Biogeographic and ecological aspects. Biogeographia, 24, 319-327.

Bianchi, C.N. \& Morri, C. (2004). Climate change and biological response in Mediterranean Sea ecosystems-a need for broad-scale and long-term research. Ocean Challenge, 13(2), 32-36.

Bilecenoğlu, M., Kaya, M., Cihangir, B. \& Çiçek, E. (2014). An updated checklist of the marine fishes of Turkey. Turkish Journal of Zoology, 38, 901929.

Bortone, S.A., Van Tassell, J., Brito, A., Falcón, J.M. \& Bundrick, C.M. (1991). A visual assessment of the inshore fishes and fishery resources off El Hierro, Canary Islands: a baseline survey. Scientia Marina, 55, 529-541.

Bullock, A.E. \& Monod, T. (1997). Myologie céphalique de deux poissons perroquets (Teleostei: Scaridae). Cybium, 21(2), 173-199.

Çoker, T. \& Akyol, O. (2014). An overview on the fish diversity in the coasts of Turkish Republic of Northern Cyprus (Mediterranean). Ege Journal of Fisheries and Aquatic Sciences, 31(2), 113-118. DOI: 10.12714/egejfas.2014.31.2.08

De Girolamo, M., Scaggiante, M. \& Rasotto, M.B. (1999). Social organization and sexual pattern in the Mediterranean parrotfish Sparisoma cretense (Teleostei: Scaridae). Marine Biology, 135(2), 353-360. DOI: 10.1007/s002270050634

Dulčić, J. \& Pallaoro, A. (2001). Some new data on Xyrichtys novacula (Linnaeus, 1758) and Sparisoma cretense (Linnaeus, 1758) from the Eastern Adriatic. Annales Series Historia Naturalis, 11(1), 35-40.

Espino, F., González, J.A., Haroun, R. \& Tuya, F. (2015). Abundance and biomass of the parrotfish Sparisoma cretense in seagrass meadows: temporal and spatial differences between seagrass interiors and seagrass adjacent to reefs. Environemental Biology of Fishes, 98, 121-133.

Filiz, H. \& Sevingel, N. (2015). A new maximum length for the parrotfish Sparisoma cretense (Linnaeus, 1758) in the Mediterranean Sea. Journal of Aquacultural Engineering and Fisheries Research, 1(3), 140-143.

Fisher, W., Schneider, M. \& Bauchot, M.L. (1987). Fiches FAO d'identification des espèces pour les besoins de la pêche. (Révision 1). Méditerranée et mer Noire.Zone de pêche 37. Vertébrés. 
Publication prepare par la FAO, résultat d'un accord entre la FAO et la Commission des Communautés Européennes (Project GCP/INT/422/EEC) financée conjointement par ces deux organizations. 2, 761-1530p, FAO, Rome.

Francour, P., Boudouresque, C. F., Harmelin, J. G., Harmelin-Vivien, M. L. \& Quignard, J. P. (1994). Are the Mediterranean waters becoming warmer? Information from biological indicators. Marine Pollution Bulletin, 28(9), 523-526.

Fricke, R., Bilecenoğlu, M. \& Sarı, H.M., (2007). Annotated checklist of fish and lamprey species (Gnathostomata and Petromyzontomorphi) of Turkey, including a Red List of threatened and declining species. Stuttgarter Beiträge zur Naturkunde Serie A (Biologie), 706, 169.

Froese, R. \& Pauly, D. Eds. (2018). Fishbase. World wide web electronic publication. 8/2018, www.fishbase.org. version.

Golani, D., Öztürk, B. \& Başusta, N. (2006). Fishes of the Eastern Mediterranean. 24, 259p, Turkish Marine Research Foundation, Istanbul, Turkey,

Guidetti, P. \& Boero, F. (2001). Occurrence of the Mediterranean parrotfish Sparisoma cretense (Perciformes: Scaridae) in south-eastern Apulia (south-east Italy). Journal of Marine Biological Associations U.K, 81, 717-719. DOI: 10.1017/S0025315401004507

Guidetti, P. \& Boero, F. (2002). Spatio-temporal variability in abundance of the parrotfish, Sparisoma cretense, in SE Apulia (SE Italy, Mediterranean Sea). Italian Journal of Zoology, 69(3), 229-232. DOI: 10.1080/11250000209356464

Kampouris, T.E., \& Batjakas, I.E. (2018). The northernmost record of the thermophilic Mediterranean parrotfish Sparisoma cretense (Linnaeus, 1758) (Perciformes, Scaridae) in the eastern Mediterranean Sea (northwestern Aegean Sea). Annales Series Historia Naturalis, 28(2), 111-116.

Kruschel, C., Zubak, I. \& Schultz, S. T. (2012). New records of the parrot fish, Sparisoma cretense, and the cleaver wrasse, Xyrichtys Novacula, by visual census in the southern Adriatic. Annales Series Historia Naturalis, 22, 47-53.

Lejeusne, C., Chevaldonné, P., Pergent-Martini, C., Boudouresque, C.F. \& Pérez, T. (2010). Climate change effects on a miniature ocean: the highly diverse, highly impacted Mediterranean Sea. Trends in Ecology \& Evolution, 25(4), 250-260.

Lewis, S.M. \& Wainwright, P.C. (1985). Herbivore abundance and grazing intensity on a Caribbean coral reef. Journal of Experimental Marine Biology and Ecology, 87(3), 215-228.

Louisy, P. (2015). Europe and Mediterranean marine fish. Identification guide. Ulmer, Paris, 182-183.

Lök, A., Gül, B., Ulaş, A., Düzbastılar, F.O. \& Metin, C. (2008). Diel variations on the fish assemblages at artificial reefs in two different environments of the Aegean Sea (Western Coast of Turkey). Turkish Journal of Fisheries and Aquatic Sciences, 8, 79-85.

Marletta, G. \& Lombardo, A. (2020). Assessment of grazing impact on deep canopy-forming species in the western Ionian Sea, Central Mediterranean. International Journal of Aquatic Biology, 8(5), 365-376.

Marras, S., Cucco, A., Antognarelli, F., Azzurro, E., Milazzo, M., Bariche, M., Butenschön, M., Kay, S, Di Bitetto, M, Quattrocchi, G, Sinerchia, M. \& Domenici, P. (2015). Predicting future thermal habitat suitability of competing native and invasive fish species: from metabolic scope to oceanographic modelling. Conservation Physiology, 3, 1-14. DOI: 10.1093/conphys/cou059

Monod, T., Hureau, J.C. \& Bullock, A.E. (1994). Ostéologie céphalique de deux poissons perroquets (Scaridae: Teleostei). Cybium, 18(2), 135-168.

Oliveira, M.T., Santos, M.N., Coelho, R., Monteiro, V., Martins, A. \& Lino, P.G. (2015). Weight-length and length-length relationships for reef fish species from the Cape Verde archipelago (tropical north-eastern Atlantic). Journal Applied Ichthyology, 31(1), 236-241. DOI: 10.1111/jai.12497

Öğretmen, F., Yılmaz, F. \& Torcu Koç, H. (2005). An investigation on fishes of Gokova Bay (southern Aegean Sea). BAUN, Journal of Science and Technology, 7(2), 19-36.

Parmesan, C., Ryrholm, N., Stefanescu, C., Hill, J.K., Thomas, C.D., Descimon, H. \& Tennent, W.J. (1999). Poleward shifts in geographical ranges of butterfly species associated with regional warming. Nature, 399, 579-583. DOI: $10.1038 / 21181$

Parmesan, C. \& Yohe, G. (2003). A globally coherent fingerprint of climate change impacts across natural systems. Nature, 421, 37-42.

Perdikaris, C., Konstantinidis, E. \& Paschos, I. (2012). Sparisoma cretense (L. 1758) from the NW Ionian coast of Greece. Mediterranean Marine Science, 13(1), 164.

Petrakis, G., \& Papaconstantinou, C. (1990). Biology of Sparisoma cretense in the Dodecanese (Greece). Journal of Applied Ichthyology, 6, 14-23.

Pallaoro A, \& Dulčić J. (2004) Some biological information of the parrotfish Sparisoma cretense (Linnaeus 1758) from the eastern Adriatic. Rapports et proces verbaux des réunions Commission internationale pour l'exploration scientifique de la mer Méditerranée, 37, 418p.

Petrakis, G. \& Papaconstantinou, C. (1990). Biology of Sparisoma cretense in the Dodecanese (Greece). Journal of Applied Ichthyology, 6, 14-23.

Pollard, D., Yokes, B., Francour, P., Rocha, L.A., Choat, J.H., Clements, K.D., Russell, B., Myers, R., Lazuardi, M.E., Muljadi, A., Pardede, S. \& Rahardjo, P. (2012). Sparisoma 
cretense. The IUCN Red List of Threatened Species: e.T190710A17796845. DOI: 10.2305/IUCN.UK.2012.RLTS.T190710A17796 845.en.

Quignard, J.P. \& Pras, A. (1986). Scaridae. In Whitehead P.J.P. et al. (Eds.). Fishes of the north-eastern Atlantic and the Mediterranean, 2, UNESCO, Paris, 943-944.

Randall, J.E. (1990). Scaridae, In: Quero, J.C., Hureau, J.C., Karrer, C., Post, A. \& Saldanha, L. (Ed). Check-list of the fishes of the eastern tropical Atlantic. (CLOFETA). JNICT, Lisbon; SEI, 2, 883-887p, Unesco, Paris.

Riera, F., Grau, A., Grau, A.M., Pastor, E., Quetglas, A. \& Pou, S. (1999). Ichthyofauna associated with drifting floating objects in the Balearic Islands (Western Mediterranean). Scientia Marina, 63, 229-235.

Rotjan, R.D. \& Lewis, S.M. (2006). Parrotfish abundance and selective corallivory on a Belizean coral reef. Journal of Experimental Marine Biology and Ecology, 335, 292-301.

Torcu, H., Aka, Z. \& İşbilir, A. (2001). An investigation on fishes of the Turkish Republic of northern Cyprus. Turkish Journal of Veterinary and Animal Sciences, 25, 155-159.

Walther, G. R., Post, E., Convey, P., Menzel, A., Parmesan, C., Beebee, T. J. C., Fromentin, JM., Hoegh-Guldberg, O. \& Bairlein, F. (2002). Ecological responses to recent climate change. Nature, 416, 389-395.

Ventura, D., Colloca, F. \& Ardizzone, G. (2019). Settlement evidence of the Mediterranean parrotfish Sparisoma cretense (Teleostei: Scaridae) in the Central Tyrrhenian Sea (Giglio Island, Italy). BioInvasions Records, 8(2), 413418. DOI: 10.3391/bir.2019.8.2.23

Yapıcı, S., Filiz, H. \& Bilge, G. (2016). Northwards range expansion of Sparisoma cretense (Linnaeus, 1758) in the Turkish Aegean Sea. Journal of Aquacultural Engineering and Fisheries Research, 2(4), 201-207. DOI: 10.3153/JAEFR16022 